Primljen / Received: 24.3.2017. Ispravljen / Corrected: 10.7.2017.

Prihvaćen / Accepted: 2.11.2017. Dostupno online / Available online: 10.12.2018.

\section{Numerical and analytical model for serviceability limit states of RC elements}

Authors:

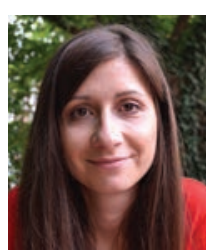

Marija Docevska, MSc. CE

Ss. Cyril and Methodius University

Faculty of Civil Engineering

docevska.marija@yahoo.com

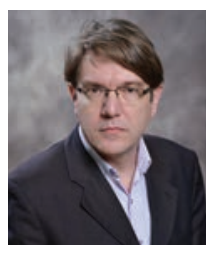

Prof. Toni Arangjelovski, PhD. CE

Ss. Cyril and Methodius University

Faculty of Civil Engineering

arangelovskitoni@gf.ukim.edu.mk

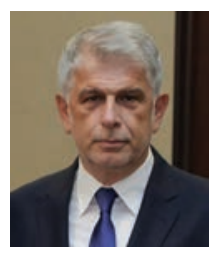

Prof. Goran Markovski, PhD. CE

Ss. Cyril and Methodius University

Faculty of Civil Engineering

markovski@gf.ukim.edu.mk

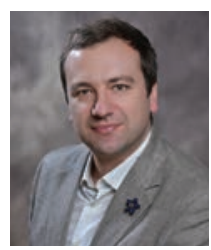

Assit.prof. Darko Nakov, PhD. CE Ss. Cyril and Methodius University Faculty of Civil Engineering nakov@gf.ukim.edu.mk
Preliminary note

Marija Docevska, Toni Arangjelovski, Goran Markovski, Darko Nakov

Numerical and analytical model for serviceability limit states of RC elements

A numerical and analytical model for prediction of serviceability limit states of flexural reinforced concrete members is outlined. The considered beam elements are investigated under short-term and long-term bending load. The numerical and analytical model is validated using existing experimental data. Both analyses provide reliable estimation of in-service deflections. A multi-directional fixed crack model is included in the numerical model to account for the non-linear post-cracking behaviour of concrete. For long-term analysis, time-dependent effects of concrete, creep and shrinkage are employed in both models through viscoelastic concrete behaviour.

Key words:

creep and shrinkage, long-term deflections, moment-curvature, crack pattern, tension-stiffening

Prethodno priopćenje

Marija Docevska, Toni Arangjelovski, Goran Markovski, Darko Nakov

Numerički i analitički model za granična stanja uporabljivosti elemenata

Opisan je numerički i analitički model za predviđanje graničnih stanja uporabljivosti savojnih armiranobetonskih elemenata. Predmetni gredni elementi ispituju se pod kratkotrajnim i dugotrajnim savojnim opterećenjem. Numerički i analitički model provjeren je uporabom postojećih eksperimentalnih podataka. Obje analize daju pouzdanu procjenu progiba tijekom uporabe. Model višesmjerne nepokretne pukotine uključen je u numerički model kako bi se uzelo u obzir nelinearno ponašanje betona nakon stvaranja pukotina (raspucavanja). Za dugoročnu analizu u oba modela primjenjuju se vremenski ovisni učinci betona, puzanja i skupljanja kroz viskoelastično ponašanje betona.

Ključne riječi:

puzanje i skupljanje, dugotrajne deformacije, moment zakrivljenosti, razvoj pukotina, nosivost na vlak

Vorherige Mitteilung

Marija Docevska, Toni Arangjelovski, Goran Markovski, Darko Nakov

Nummerisches und analytisches Modell für Grenzzustände der Verwendbarkeit von verstärkten Elementen

Beschrieben wird das nummerische und analytische Modell für die Vorhersage von Grenzzuständen der Verwendbarkeit von flexiblen Stahlbetonelementen. Das betreffende Balkenelement wird unter kurzzeitiger und langfristiger Biegebelastung getestet. Das nummerische und analytische Modell wurde durch Anwendung vorhandener experimenteller Daten überprüft. Beide Analysen geben eine zuverlässige Einschätzung der Verbiegung während des Gebrauchs ab. Das Modell des mehrwegigen unbeweglichen Risses wird im nummerischen Modell einbezogen, um das nicht lineare Verhalten des Betons nach Auftreten von Rissen (Spaltung) zu berücksichtigen. Für eine Langzeitanalyse bei beiden Modellen werden zeitabhängige Auswirkungen des Betons, Kriechen und Schrumpfen durch hochelastisches Verhalten des Betons, angewendet. 


\section{Introduction}

In structural design of some deflection sensitive elements (such as beams and slabs), deflection and crack control at service load levels are usually major considerations, which is why accurate modelling of concrete stiffness after cracking is required. Numerous cases have been reported of structures that were in compliance with ultimate limit states requirements, but were nevertheless affected by excessive deflection or cracking. In many of these cases, failure to adequately account for creep and shrinkage at the design stage was found to be the main reason for such deficiencies [1].

In order to meet serviceability requirements, a concrete structure must perform its intended function throughout its working life [1]. Therefore, three most common serviceability limit states, namely, cracking, deflections and stress level in concrete and reinforcement must be controlled.

In this paper, the main focus is set on numerical and analytical analysis of time variation of stresses and strains, mid-span deflections, and crack pattern in RC bending elements under sustained load. The authors present a comparison of numerical and analytic results with existing experimental data on various beams under short-term and different levels of sustained load.

A reliable calculation of serviceability limit states of reinforced concrete elements is very often not straightforward. In fact, it is almost always burdened by difficulties with regard to estimation of non-linear behaviour of concrete under sustained service load. Some of the most significant aspects that make this calculation complex include: random distribution of concrete tensile strength along elements, effect of creep and shrinkage, time variation of tension stiffening, and variation of elasticity modulus of concrete over time [2]. Some of these parameters cannot be considered by means of the existing analytical procedure proposed in codes, and so the application of numerical models becomes essential.

The necessity of applying a numerical model for the prediction of serviceability limit states additionally arises from the inherently random cracking process, which complicates prediction of deflections. An accurate prediction of deflection is largely affected by the location and spacing of cracks, which are analytically unpredictable due to random factors that control their spreading [3]. For example, the results of crack calculation procedures proposed in Eurocode 2 [4] and Model Code 2010 [5] are only the maximum crack width $w_{m}$ and the maximum crack space $s_{m^{\prime}}$ which are sufficient for assessing the durability state, but do not ensure accurate determination of deflection of sensitive structural elements. In addition, visual impression of the crack pattern and response of a member can only be obtained by numerical analysis using the FE software. Therefore, a numerical model for predicting serviceability limit states is not only an alternative method in analytical terms but, in many cases, it is actually the only method that can be applied.

\section{Analysed element}

In order to predict the time-dependent behaviour of RC beams under different levels of sustained load, a numerical and analytical model was applied on a reference beam made of concrete class c30/37 subjected to four-point bending. These elements were experimentally tested at the Department of Concrete Structures, Faculty of Civil Engineering - Skopje, Republic of Macedonia [6]. A detailed description of the experimental program can be found elsewhere [7]. The geometry, reinforcement, and load scheme, are depicted in Figure 1, while the experimentally obtained material properties used in further analysis are summarized in Table 1.

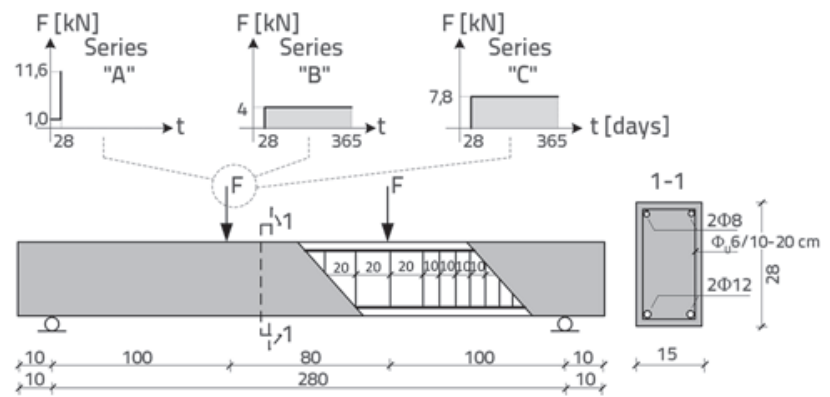

Figure 1. Geometry, reinforcement, and load scheme for RC reference beam

Table 1. Mechanical properties of concrete and reinforcement

\begin{tabular}{|c|c|c|c|c|c|}
\hline & \multicolumn{3}{|c|}{ Concrete } & \multicolumn{2}{c|}{ Reinforcement } \\
\hline Property & $f_{c k}[\mathrm{MPa}]$ & $f_{c t}[\mathrm{MPa}]$ & $E_{c m}[\mathrm{MPa}]$ & $E_{s}[\mathrm{MPa}]$ & $\sigma_{y}[\mathrm{MPa}]$ \\
\hline Value & 31.90 & 2.90 & 30483 & 200100 & 400 \\
\hline
\end{tabular}

Mechanical properties of concrete, namely compressive strength and splitting tensile strength, were obtained at the concrete age of 40 days on cube-shaped control specimens, while the modulus of elasticity was tested at the same concrete age on cylindrical specimens using hydraulic press. Besides concrete mechanical properties, the modulus of elasticity of reinforcement and its yield strength were determined experimentally. The corresponding results are shown in Table 1. The analysed beam elements of equal geometry differed only in the type of load, as displayed in Figure 1. According to the type of load, they were generally divided into two groups. The first group consisted of one series of beams "A", in which the beams were investigated under short-term service load $\left(F_{s}=11.6 \mathrm{kN}\right)$. The second group consisted of two series of beams "B" and " $C$ ". The beams from this group were subjected to long-term load over a one year period. The intensity of permanent load in the beam series " $\mathrm{B}$ " ( $\left.\mathrm{F}_{\mathrm{g}}=4 \mathrm{kN}\right)$ represented $34 \%$ of the service load $\left(F_{s}=11.6 \mathrm{kN}\right)$ and was lower than the load which produced the first crack. The intensity of load in the beam series " $\mathrm{C}$ " $\left(\mathrm{F}_{\mathrm{g}+\mathrm{q} / 2}\right.$ $=7.8 \mathrm{kN}$ ) amounted to $67 \%$ of the service load and produced cracks immediately after its application. 


\section{Analytical model}

\subsection{State of stress and strain}

The well-known Age-Adjusted Effective Modulus Method (AAEMM) proposed by Bazant was applied for predicting timedependent effects of concrete under sustained load.

With the known creep coefficient, shrinkage strain, and age coefficient, and under constant environmental conditions, this algebraic relation enables calculation of stresses and strains in concrete at any time $t$. Basic equations that are used to compute concrete and reinforcement stresses and strains over time are given below [8]. They can be used for uncracked and cracked sections respecting the reacting area of concrete. Stress and strain in the most compressed concrete fibre at the initial time $t_{0}$, Eq. (1) and Eq. (2):

$\sigma_{c}\left(t_{0}\right)=\frac{N_{i}}{A_{i}}+\frac{M_{i}}{l_{i}} \cdot y_{i}$

$\varepsilon_{c}\left(t_{0}\right)=\varepsilon_{\text {centroid }}\left(t_{0}\right)+\frac{1}{r\left(t_{0}\right)} \cdot y_{c}$

Stress in tension and compression reinforcement at the initial time $t_{0}$,Eq. (3):

$\sigma_{s}\left(t_{0}\right)=n \cdot \sigma_{c}\left(t_{0}\right)=\frac{E_{s}}{E_{c}} \cdot \sigma_{c}\left(t_{0}\right)$

Stress and strain in the most compressed concrete fibre at the final time $t$, Eq. (4) and Eq. (5):

$\sigma_{c}(t)=\sigma_{c}\left(t_{0}\right)+\Delta \sigma_{c}(t)=\sigma_{c}\left(t_{0}\right)+\left[-\left(\frac{N_{i}^{*}}{A_{i}^{*}}+\frac{M_{i}^{*}}{l_{i}^{*}} \cdot y_{i}^{*}\right)\right]$

$\varepsilon_{c}(t)=\varepsilon_{c}\left(t_{0}\right)+\Delta \varepsilon_{c}(t)=\varepsilon_{c}\left(t_{0}\right)+\Delta \varepsilon_{\text {centroid }}(t)+\frac{1}{\Delta r(t)} \cdot y_{c}$

Stress in tension and compression reinforcement at the final time $t$, Eq. (6) and Eq. (7):

$\sigma_{s}(t)=\sigma_{s}\left(t_{0}\right)+\Delta \sigma_{s}(t)=\sigma_{s}\left(t_{0}\right)+\left[-\left(n^{*}\left(\frac{N_{i}^{*}}{A_{i}^{*}}+\frac{M_{i}^{*}}{l_{i}^{*}} \cdot y_{i}^{*}\right)+\frac{N_{s}}{A_{s}}+\frac{M_{s}}{l_{s}} \cdot y_{s}\right)\right]$

$n^{*}=\frac{E_{s}}{E_{c}^{*}}=\frac{E_{s}}{E_{c}\left(t_{0}\right)} \cdot\left(1+\chi\left(t, t_{0}\right) \cdot \phi\left(t, t_{0}\right)\right)$

where, according [8] are.

$M_{i} \& N_{i} \quad$ - the bending moment and axial force, respectively, reduced in the centroid of an idealized cross-section

$A_{i^{\prime}} I_{i} \& y_{i}$ - geometrical characteristics of an idealized crosssection

$1 / r\left(t_{0}\right) \quad$ - urvature in the initial time $t_{0}$

$\mathrm{M}_{i}^{*} \& \mathrm{~N}_{i}^{*}$ - nfluences in the idealized age-adjusted section

$A_{i}^{*}, J^{*} \& y_{i}^{*}$ - geometrical characteristics of an idealized ageadjusted section

$1 / \Delta r(t) \quad$ - the curvature change over time $t$
$M_{s} \& N_{s}$ - the bending moment and axial force in reinforcement resulting from free unrestricted shrinkage and creep deformations (approximation: no bond between concrete and reinforcement bars)

$A_{s^{\prime}} I_{s} \& y_{s}$ - geometrical characteristics of reinforcement

$\chi\left(t, t_{0}\right) \quad$ - the concrete age coefficient

$\phi\left(t, t_{0}\right) \quad$ - the creep coefficient.

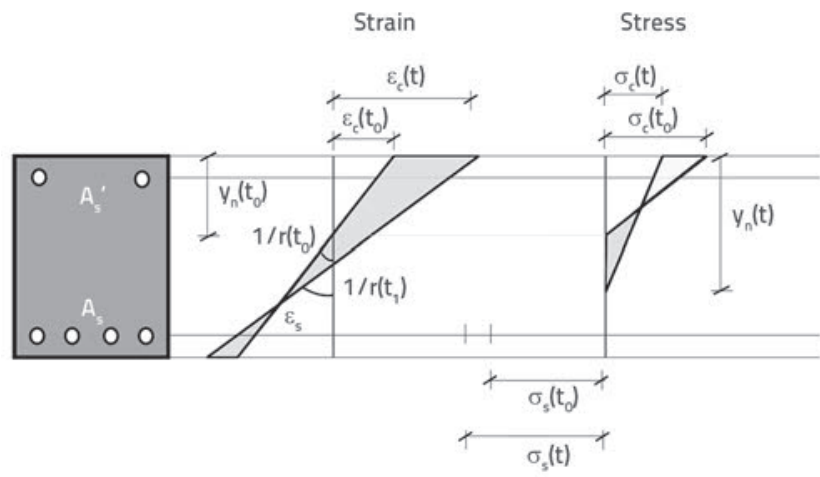

Figure 2. Evolution of stress and strain in cross-section over time $\left(t-t_{0}\right)[2]$

As displayed in Figure 2, the effects of creep and shrinkage affect stresses and strains in concrete and consequently the embedded reinforcement, which is why they should not be neglected. Their influences result in an increase of curvature and drop of neutral axis towards the bottom reinforcement over time (Figure 2).

\subsection{Instantaneous and time-dependent deflections}

The general procedure of computing short-term deflections involves double integration of mean curvature over the element length. The mean curvature must be used, especially in the calculation of cracked elements, due to variation of curvature in a portion between two cracks as a result of bond stress distribution along the bars. The Simpson's rule is applied here for integration of the product of mean curvature $k_{s, m}$ and virtual bending moment along the element length, which directly yields deflection $a$ at the desirable section (Eq. 8) [11]:

$a=\int_{0}^{1} k_{s, m}(t) \cdot \bar{M}(x) \cdot d x$

The deflection of a reinforced concrete flexural member under a sustained load increases with time as a result of three main effects [1]:

- time-dependent cracking;

- reduction of tension stiffening $\Delta \delta$ over time ( $\Delta \delta$ decreases over time);

- increase in curvature in each cross-section over time due to creep and shrinkage of concrete.

Beebly \& Scott and Gilbert [9] have shown that the tension stiffening effect decreases over time under sustained load, which 
is probably due to the combined effects of tension produced by creep, and shrinkage induced micro-cracking around steel bars. Almost every code explicitly or implicitly considers this longterm tension stiffening effect, but no code puts time scale for the loss of beneficial effects of tension stiffening. In order to obtain an accurate estimation of long-term deflections, this must be properly taken into account [10].

The above described procedure can be employed, with some modifications, for calculating the long-term deflection. The method involves evaluation of mean curvature over the considered time $t$, as the sum of the initial curvature and the increase in curvature due to time-dependent effects, namely creep and shrinkage. Here, these effects are employed through the so-called reinforcement $k_{s^{\prime}}$ creep $k_{\phi}$ and shrinkage $k_{c s}$ curvature coefficients [12]. The bilinear interpolation method is also used to account for the presence of cracks in concrete, i.e. to account for the tension stiffening effect through the distribution coefficient $\zeta$, as suggested in Eurocode 2 (Eq. 9) (Figure 3).

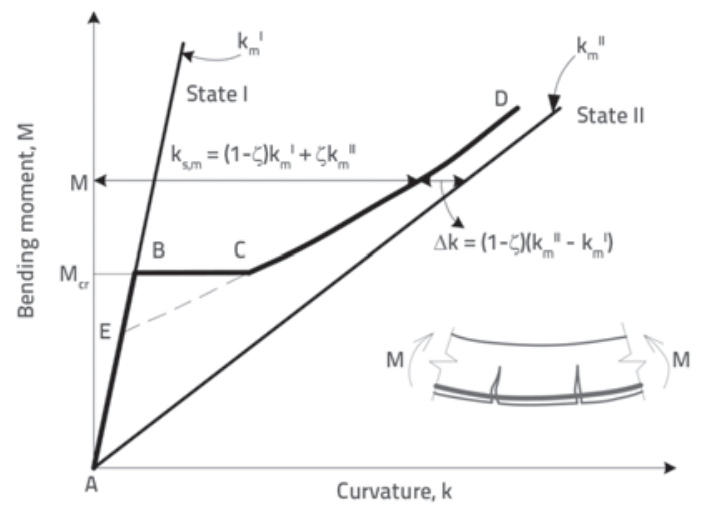

Figure 3. Bending moment versus curvature of reinforced concrete member in flexure [12]

$\zeta=1-\beta_{1} \beta_{2}\left(\frac{M_{c r}}{M}\right)^{2}$

where $\beta_{1}=1.0$ for deformed bars, and 0.5 for plain bars; $\beta_{2}=$ 1.0 for the single short-term load and 0.5 for the repeated or sustained load; $M_{c r}$ is the moment causing the first crack, and $M$ is the moment under consideration [4].

This procedure is relatively crude because it does not account for the loss of tension-stiffening over time - a concrete phenomenon, which is still not employed in the current code procedures.

Even for the most simple cases encountered in engineering practice, it is necessary to double integrate the curvature along the element length in order to obtain a reliable estimation of inservice deflections. Due to the extent and calculation difficulties of this procedure, deflection calculations are performed in almost every practical case according to one of simplified procedures proposed in the current codes. Due to their inherent simplicity, they include crude assumptions of complex concrete effects, such as cracking, tension-stiffening, creep, and shrinkage. In many practical cases, these serviceability provisions inadequately and unconservatively model the in- service behaviour of concrete structures and must, therefore, be used with caution.

A commonly used approach for deflection calculation in the codes ( $\mathrm{ACl}, \mathrm{AS3600}$, etc.), involves a well-known equation for effective stiffness developed by Branson. The tensionstiffening effect in Branson's model is simply employed through an average effective moment of inertia given with the empirical equation (10) [1]:

$I_{e f}=\left(\frac{M_{c r}}{M_{a}}\right)^{m} I_{g}+\left[1-\left(\frac{M_{c r}}{M_{a}}\right)^{m}\right] I_{c r} \leq I_{g}$

where:

$\mathrm{M}_{\mathrm{cr}}$ - he cracking moment

$\mathrm{M}_{\mathrm{a}}$ - the maximum applied moment

$\mathrm{I}_{\mathrm{ef}}$ - the effective moment of inertia

$I_{g}$ - the gross moment of inertia

$I_{c r}$ - the moment of inertia of the cracked section, and the power

$m$ - the empirically estimated value that can range from 3 to 4 (for lightly reinforced elements, value 4 is recommended).

Instantaneous and long-term deflections of concrete elements can be calculated using equations (11) and (12), respectively, as proposed by many codes:

$a_{0}=K \frac{M}{E_{c} \cdot l_{\text {ef }}} L^{2}$

$a_{t}=K_{r} \cdot \phi\left(t, t_{0}\right) \cdot a_{0}{ }^{g}=\left(1-0.6 \frac{A^{\prime}}{A}\right) \cdot \phi\left(t, t_{0}\right) \cdot a_{0}{ }^{g}$

where:

$\mathrm{K} \quad$ - the coefficient depending on boundary conditions of the element and type of load

M - the maximum service moment

$\mathrm{E}_{\mathrm{c}} \quad$ - the modulus of elasticity of concrete

$L \quad$ - the span of the element

$\mathrm{K}_{\mathrm{r}} \quad$ - the empirical coefficient taking into account beneficial effect of compression reinforcement on the creep and shrinkage deformations

$A^{\prime} / A$ - the ratio between compression and tension reinforcement area

$\phi\left(t, t_{0}\right)$ - the creep coefficient

$\mathrm{a}_{0}{ }^{\mathrm{g}} \quad$ - the instantaneous deflection caused by permanent load.

The reference beam deflection results obtained with these equations will be presented and discussed in more detail in Section 5.

\section{Numerical model}

Numerical analysis for the serviceability limit states of analysed elements was carried out using the FEM software DIANA Version 9.4.3. 


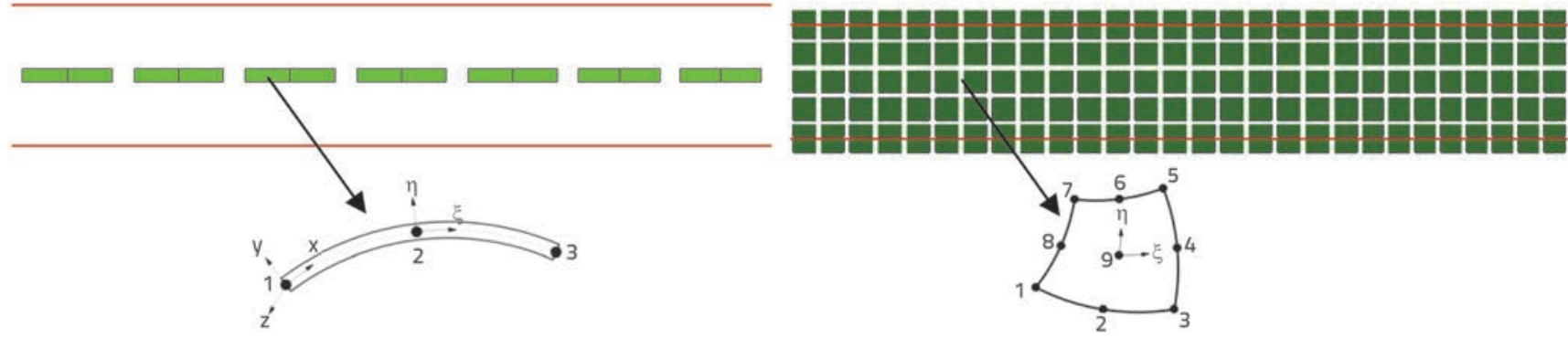

Figure 4. Mathematical model with beam FE (left) and plane stress FE (right)

\subsection{Mathematical models}

Two distinct mathematical models were applied in the analysis: a model with beam finite elements (1D analysis) and a model with plane stress elements (2D analysis) (Figure 4). In the first mathematical model, beam elements consisting of three nodes (CL9BE) were applied based on the Mindlin-Reissner theory. They represent the elements that are fully numerically integrated over their cross-section and along their axis. For integration of these elements along their axis and over their cross-section, the Gaussian integration scheme and the Simpson's integration were used for two and nine nodes, respectively. In the second mathematical model, a two-dimensional quadrilateral isoparametric plane stress element with eight nodes around the element edges, and one in the middle (CQ18M), was used (Figure 4).

In both cases, the compression and tension reinforcement was modelled by means of the embedded technique of modelling with special elements. These special elements add stiffness to the elements in which they are embedded, i.e. to the elements known as "mother elements" (in this case, concrete elements) [13].

A physical nonlinear analysis was carried out in Diana 9.4.3 software to account for the post-cracking concrete behaviour. The main source of nonlinear behaviour of concrete is mainly the presence of cracks. A multi-directional fixed crack model was applied to analyse the elements in a cracked state. This model seems to be the most appropriate and favourable cracking model for bending cases. The iterative-incremental procedure, namely the regular Newton-Raphson method, was used for accurate and fast convergence. The optimal load increment was automatically determined in combination with the "Arc-length" control and energy based convergence criteria.

\subsection{Multi-directional fixed crack model}

Since cracks in concrete occur in a very random manner, the smeared crack approach is recommended via the multidirectional fixed crack model. Every smeared crack model is based on the decomposition of total strain into an elastic strain and crack strain (Eq. 13) [14]. The applied multi-directional fixed crack model ranks among the most commonly used and highly favoured smeared crack models. Its additional capability involves modelling a number of cracks that occur simultaneously (Eq.14) [14]. $\varepsilon=\varepsilon^{e l}+\varepsilon^{c r}$

$\varepsilon^{c r}=\varepsilon^{c r}+\varepsilon_{1}^{c r}+\varepsilon_{2}^{c r}+\ldots$

where:

$\varepsilon^{e l}$ - the elastic strain

$\varepsilon^{c r} \quad$ - he crack strain

$\varepsilon_{1}^{c r} \quad$ - the strain in crack number 1

$\varepsilon_{2}^{c r}$ - the strain in crack number 2 as a result of crack number 1 , etc.

The multi-directional fixed crack model in Diana 9.4.3 was defined through three concrete phenomena: tension softening, tension cut-off, and shear retention (Figure 5).
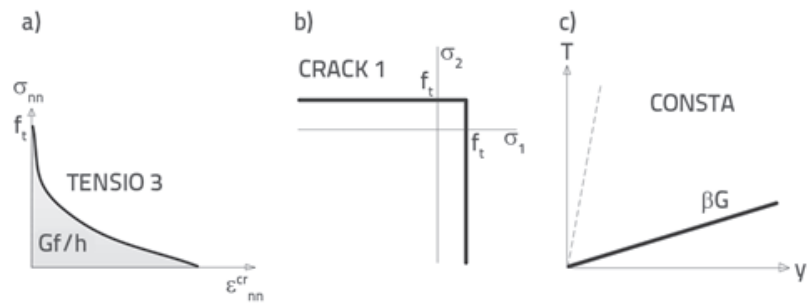

Figure 5. Curves applied in numerical model for tension softening, tension cut-off and shear retention: a) Non-linear softening curve; b) Constant tension cut-off; c) Constant shear retention

The input used in Diana 9.4.3 for defining these three phenomena is specified in Table 2 .

Table 2. Input parameters for multi-directional fixed crack

\begin{tabular}{|c|c|c|}
\hline Parameters & $\begin{array}{c}\text { Codes in } \\
\text { Diana }\end{array}$ & Input \\
\hline Tension softening curve & TENSIO 3 & $\begin{array}{c}\text { Nonlinear } \\
\text { (Moelands et al.) }\end{array}$ \\
\hline Fracture energy & Gf & $0.06 \mathrm{~N} / \mathrm{mm}$ \\
\hline Crack bandwidth & h & 50 mm \\
\hline Tension cut-off & CRACK 1 & Constant \\
\hline Shear retention curve & TAUCRI 1 & Constant \\
\hline Shear retention factor & $\beta$ & 0.50 \\
\hline
\end{tabular}


The tension softening curve was defined through two specific characteristics of cracked concrete: crack bandwidth $h$ and fracture energy of concrete $G_{f}$ The crack bandwidth in a multidirectional crack model usually coincides with a dimension of a finite element $a$ (here $h=a=50 \mathrm{~mm}$ ), and represents an area in which a crack will develop [14]. The fracture energy of concrete, defined as energy required for propagation of a crack through a unit area, is calculated herein according to the expression proposed in Model Code 2010 and is influenced by the size of the aggregate $d_{\max }$ (Table 3) and the mean compression strength of concrete $f_{c m}$ (Eg.15), [5].

$G_{f}=G_{f o}\left(\frac{f_{c m}}{f_{c m o}}\right)^{0.70}$

where:

$\mathrm{G}_{\mathrm{fo}}$ - the fracture energy base value dependent on the aggregate size of concrete (Table 3 )

$\mathrm{f}_{\mathrm{cmo}}$ - the recommended constant value equal to $10 \mathrm{MPa}$

$f_{c m} \quad$ - he mean compression strength of concrete.

Table 3. Base values of fracture energy $G_{f_{0}}\left[\mathrm{Nmm} / \mathrm{mm}^{2}\right]$

\begin{tabular}{|c|c|}
\hline $\boldsymbol{d}_{\text {max }}[\mathrm{mm}]$ & $\boldsymbol{G}_{f 0}\left[\mathrm{Nmm} / \mathrm{mm}^{2}\right]$ \\
\hline 8 & 0.025 \\
\hline 16 & 0.030 \\
\hline 32 & 0.058 \\
\hline
\end{tabular}

The time-dependent effects of concrete, creep and shrinkage, were employed in the model through viscoelastic behaviour of concrete. The viscoelastic behaviour of concrete can be analysed in Diana 9.4.3 through the Maxwell rheological chain model, which is defined by the standard creep functions proposed in
Model Code 1990 [14]. The creep and shrinkage were applied in time steps on a logarithmic scale for a given period of one year.

\section{Results of analysis}

The numerical and analytical results were compared with experimental data. The results of time variation of stresses and strains in concrete and reinforcement, short-term and long-term deflections, and the crack pattern, will be presented schematically.

\subsection{Stresses and strains}

The state of stress in the compressed concrete $\sigma_{c}$ tension $\sigma_{s}$ and compression $\sigma_{s^{\prime}}$ reinforcementispresented in Table 4 for the group of beams subjected to sustained load (Series "B" and "C"). It is obvious that the stress in the most compressed concrete fibre reduces over time, while the stress in the compression reinforcement increases rapidly as a result of the required equilibrium of internal forces. At the same time, an insignificant increase of stress can be observed in the tension reinforcement (Table 4).

The first row of Table 4, which presents the experimentally obtained stresses in compressed concrete, remains unfilled because these stresses could not be obtained directly from the measured strains as a result of stress redistribution in concrete section due to the creep and shrinkage effects. However, stresses in the tension and compression reinforcement can be obtained directly from strain measurement.

An increase of stress in compression reinforcement over time can be observed in both cases, i.e. for uncracked and cracked beams. In case of the beam series "B" (uncracked elements), the stress in compression reinforcement over time ( $t=365$ days) exceeds by almost ten times the stress observed immediately after

Table 4. Stress in the most compressed concrete fibre, tension and compression reinforcement at initial $\left(t_{0}=28 d a y s\right)$ and final time $(t=365 d a y s)$ as obtained experimentally, numerically and analytically

\begin{tabular}{|c|c|c|c|c|c|c|c|c|c|}
\hline & & & $t_{0}=28$ days & $\mathrm{t}=365$ days & & & & $\mathrm{t}_{0}=28$ days & $\mathrm{t}=365$ days \\
\hline \multicolumn{5}{|c|}{ Series of beams “B" } & \multicolumn{5}{|c|}{ Series of beams "C" } \\
\hline \multirow{4}{*}{$\begin{array}{c}\sigma_{\mathrm{c}} \\
{[\mathrm{MPa}]}\end{array}$} & \multicolumn{2}{|c|}{ Experiment } & I & I & \multirow{4}{*}{$\begin{array}{c}\sigma_{\mathrm{c}} \\
{[\mathrm{MPa}]}\end{array}$} & \multicolumn{2}{|c|}{ Experiment } & I & I \\
\hline & \multirow{3}{*}{$\begin{array}{c}\text { Analyt } \\
\begin{array}{c}\text { Numerical } \\
\text { model }\end{array}\end{array}$} & nodel & -1.91 & -1.55 & & \multicolumn{2}{|c|}{ Analytical model } & -6.87 & -3.45 \\
\hline & & Beam & -2.52 & -1.98 & & Numerical & Beam & -8.01 & -4.52 \\
\hline & & P.St. & -2.12 & -1.69 & & model & P.St. & -5.81 & -4.16 \\
\hline \multirow{4}{*}{$\begin{array}{c}\sigma_{\mathrm{s}^{\prime}} \\
{[\mathrm{MPa}]}\end{array}$} & \multicolumn{2}{|c|}{ Experiment } & -9.40 & -85.2 & \multirow{4}{*}{$\begin{array}{c}\sigma_{\mathrm{s}^{\prime}} \\
{[\mathrm{MPa}]}\end{array}$} & \multicolumn{2}{|c|}{ Experiment } & -41.20 & -140 \\
\hline & \multicolumn{2}{|c|}{ Analytical model } & -10.30 & -93.50 & & \multicolumn{2}{|c|}{ Analytical model } & -23.70 & -156.9 \\
\hline & \multirow{2}{*}{$\begin{array}{c}\text { Numerical } \\
\text { model }\end{array}$} & Beam & -16.40 & -111 & & \multirow{2}{*}{$\begin{array}{c}\text { Numerical } \\
\text { model }\end{array}$} & Beam & -51.5 & -161 \\
\hline & & P.St. & -12.4 & -101 & & & P.St. & -30.7 & -138 \\
\hline \multirow{4}{*}{$\begin{array}{c}\sigma_{s} \\
{[\mathrm{MPa}]}\end{array}$} & \multicolumn{2}{|c|}{ Experiment } & 10.0 & -2.40 & \multirow{4}{*}{$\begin{array}{c}\sigma_{\mathrm{s}} \\
{[\mathrm{MPa}]}\end{array}$} & \multicolumn{2}{|c|}{ Experiment } & 77.88 & 182 \\
\hline & \multicolumn{2}{|c|}{ Analytical model } & 9.51 & 12.50 & & \multicolumn{2}{|c|}{ Analytical model } & 147.5 & 151.9 \\
\hline & \multirow{2}{*}{$\begin{array}{c}\text { Numerical } \\
\text { model }\end{array}$} & Beam & 15.80 & -17.90 & & \multirow{2}{*}{$\begin{array}{c}\text { Numerical } \\
\text { model }\end{array}$} & Beam & 134 & 151 \\
\hline & & P.St. & 11.90 & -26.90 & & & P.St. & 101 & 138 \\
\hline
\end{tabular}




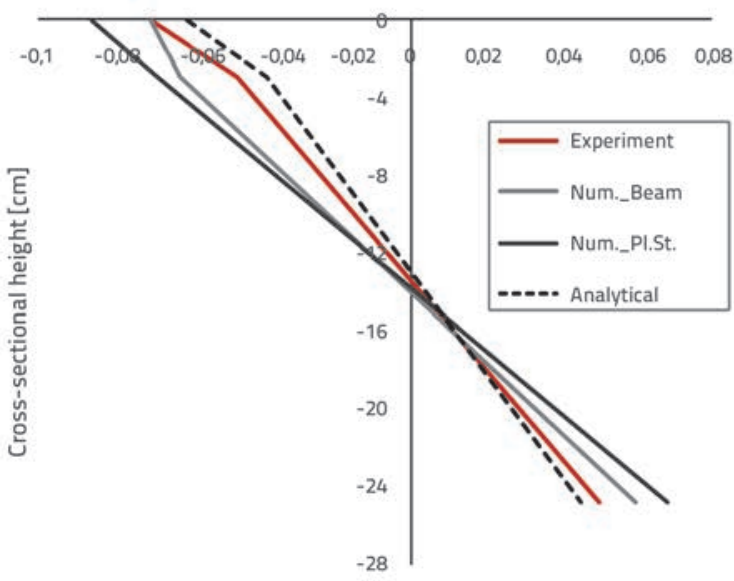

Strains $\left[\times 10^{-3}\right]$

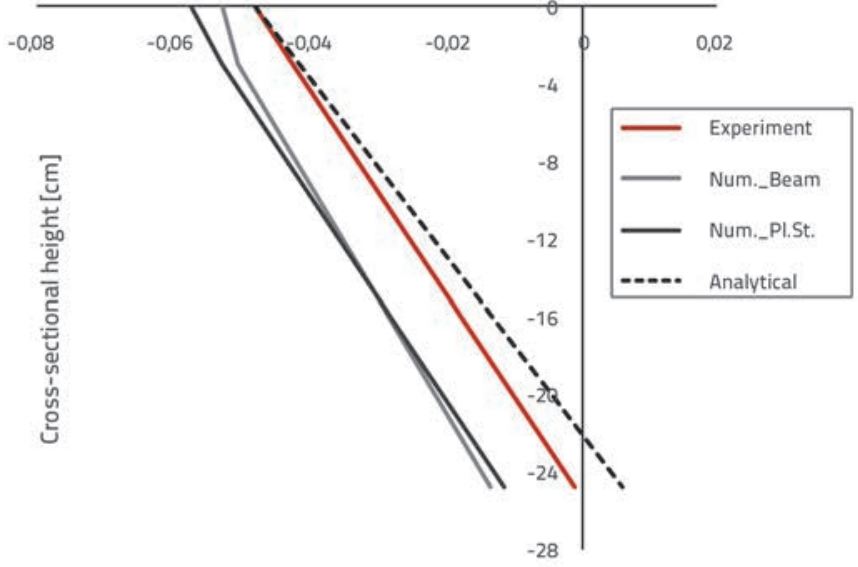

Strains $\left[\times 10^{-3}\right]$

Figure 6. Strain over cross-section (beam series "B") at initial time $t_{0}$ (left) and at final time $\mathbf{t}=\mathbf{3 6 5}$ days (right)

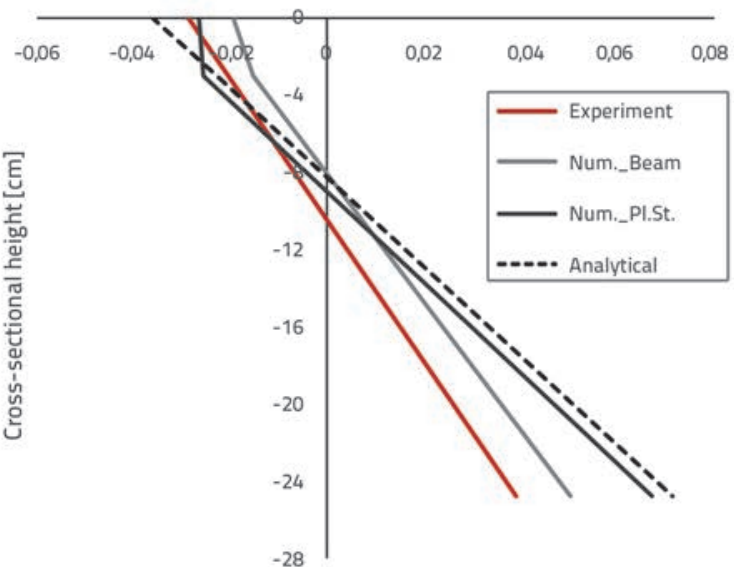

Strains $\left[\times 10^{-3}\right]$

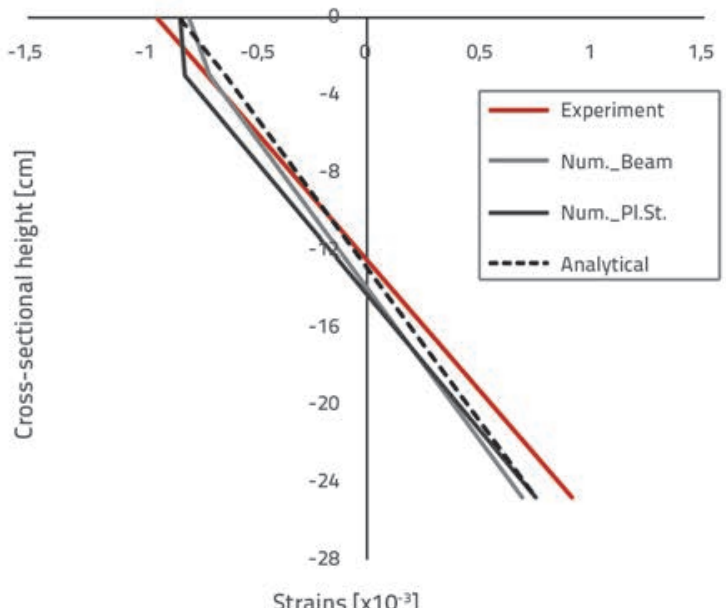

Strains $\left[\times 10^{-3}\right]$

Figure 7. Strain over cross-section (beam series "C") at initial time $t_{0}$ (left) and at final time $t=365$ days (right)

application of load. This increase in stress is less pronounced in case of the beam series "C" (cracked elements).

According to the experimentally and numerically obtained stress values, it can be observed that, due to the required equilibrium of internal forces, the initially tensile bottom reinforcement becomes compressive over time in the case when the beams remain uncracked. One of the reasons for this could be greater internal resultants in concrete produced by the creep and shrinkage effects, compared to resultants due to the external load itself. This change in the bottom reinforcement can also be observed in Figure 5 showing distribution of strains in beams "B". By contrast, the bottom reinforcement in the beam series " $\mathrm{C}$ " remains tensile during the whole analysed period of one year. Figure 5 and Figure 6 present the distribution of strain over cross-section for beam series "B" and "C", respectively. A significant increase in compressive and tensile strain can be observed over time ( $t=365$ days) in both states, i.e., cracked (Beam "C") and uncracked (Beam "B"), resulting in lowering of the neutral axis towards the bottom reinforcement. A greater lowering of the neutral axis is observed in case of the beam series "B", leading consequently to a larger increase in strain in compressive concrete. For these series of beams, the analytical model (described in 3.1) predicts better the strain in both materials, namely in concrete and reinforcement.

A smaller drop of neutral axis can be observed in the beam series " $\mathrm{C}$ ", which leads to a smaller increase in strain in both materials over time. It can be seen that the instantaneous strain in bottom reinforcement is overestimated in both models, the numerical and the analytical one (Figure 7, left), but there is a good agreement in both materials with the measured instantaneous strain in the most compressed concrete fibre, as well as with the measured strain at time $t=365$ days (Figure 7 , right).

\subsection{Instantaneous and long-term deflections}

A comparison between analytical (based on curvature integration), numerical and experimental load-deflection curves is illustrated in Figure 8 for the beam series "A" subjected to the load attaining service load $F_{s}=11.60 \mathrm{kN}$.

Short-term deflections $(23.61 \%$ ) after the cracking moment are overestimated in the numerical model with beam finite 
elements, and this overestimation increases with an increase in load. The analytical and numerical model with plane stress finite elements slightly overestimates these deflections, but provides a much better agreement with $7.78 \%$ and $5.56 \%$ deviation in terms of the experimental results, respectively.

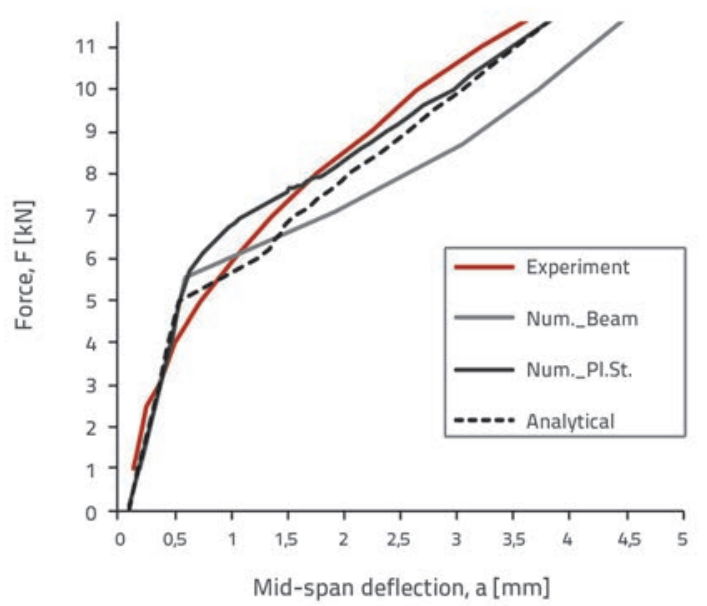

Figure 8. Comparison of short-term deflections (beam series "A") obtained analytically, numerically, and experimentally

Development of long term deflections over a period of one year is depicted in Figure 9. The same figure simultaneously presents results for both series of beams (series "B" - uncracked state, and series " $\mathrm{C}$ " - cracked state) to show the influence of the magnitude of sustained load on long-term deflections. According to these, it can be observed that the results obtained numerically and analytically are generally in close agreement with actual deflection values obtained experimentally for both beams.

Long-term deflections obtained for uncracked elements ("B"), as predicted by analytical (based on curvature integration) and numerical models, are quite similar. The actual deflections over the given period of one year are underestimated by both models. The analytical model exhibits the largest deviation in terms of measured deflections, namely, $26.06 \%$.

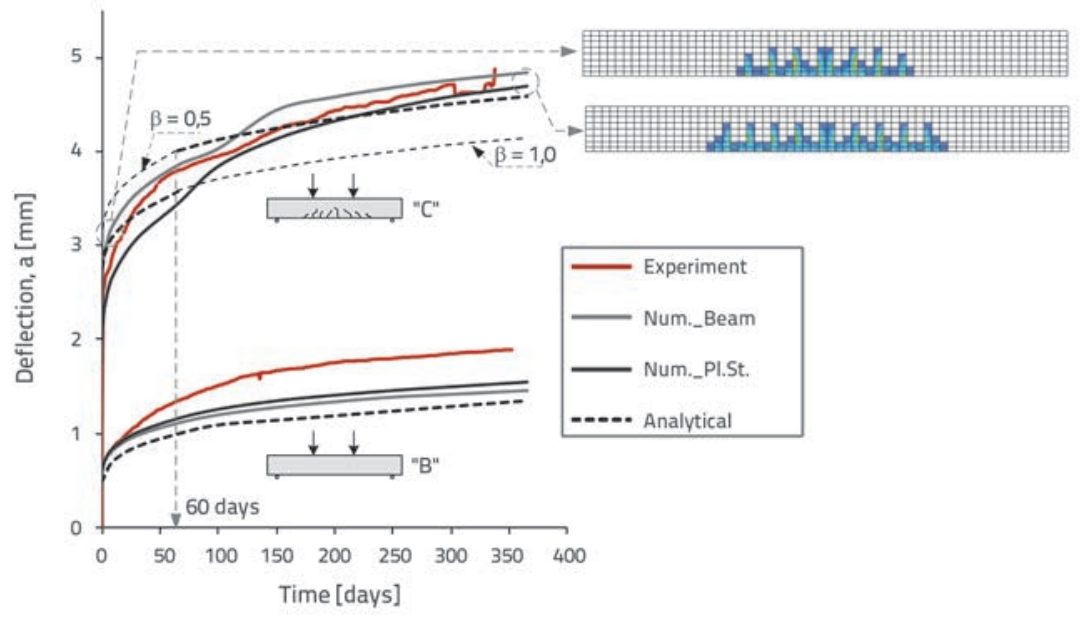

Figure 9. Comparison of development of long-term deflections (beam series "B" and "C") obtained analytically, numerically, and experimentally
Flexural cracks frequently form over time under sustained service load, and this either between the most widely spaced cracks, or in the previously uncracked regions, thereby increasing the extent of cracking (Figure 9 and Figure 11). This time-dependent cracking causes a time-dependent loss of stiffness and an increase in deflection [1].

A correlation between time-dependent flexural cracks and deflections is schematically presented in Figure 8 for cracked beams ("C"). An increase in the final deflection can be observed due to the combined effects of creep and shrinkage and consequent formation of additional time-dependent cracks. For the cracked elements ("C"), numerical models estimate a longterm deflection that is in close agreement with actual values. The numerically predicted long-term deflections of beam and plane stress elements deviate from the measured ones by $0.82 \%$ and $3.89 \%$, respectively. Analytically predicted long-term deflections for cracked elements ("C") based on curvature integration are presented in Figure 8 by means of two black dashed curves. The upper one predicts development of long-term deflections taking into account reduction of element stiffness or, more precisely, reduction of the tension-stiffening effect over time $(\beta=0.5$ in Eg. (9)). The lower curve presents long-term deflections without considering this loss of tension-stiffening due to sustained load $(\beta=1.0$ in Eg. (9)). According to results reported in literature [16], the initial tension-stiffening value reduces by about $50 \%$ after 50 to 60 days following the first loading. This points to the fact that the long-term deflections under sustained loads should be calculated with two different element stiffness values, since no codes and recommendations account for the time-dependence of the tension-stiffening effect. In this study, the long-term deflections were calculated with the initial effective stiffness until the 60th day following the first loading and, from this point in time, with a reduced stiffness due to reduction in the tensionstiffening effect over time $(\beta=0.5)$. In this way, the final longterm deflection obtained with this calculation procedure deviates by $6.35 \%$ from the measured deflection value.

Although the cracked element experiences larger final longterm deflections, the creep and shrinkage effects have a greater influence in the case of the uncracked element. This can be demonstrated using the ratio between the final and instantaneous deflection in both cases. The measured final to instantaneous deflection ratio $\left(a_{365} / a_{28}\right)$ for the beam series "B" (uncracked) amounts to 3.84, while it amounts to 2.54 for the beam series "C" (cracked). This is not unexpected since only the uncracked part of concrete is affected by creep and shrinkage [9]. A summary of deviations of the numerically and analytically calculated short-term and long-term deflections in terms of measured data is given in Table 5. The results obtained with the simplified code procedure based on Branson's model are 
Table 5. Comparison between calculated and measured instantaneous and long-term deflections for the series of beams A, B and C

\begin{tabular}{|c|c|c|c|c|c|c|c|c|c|c|c|c|c|c|c|c|c|c|}
\hline & \multicolumn{3}{|c|}{ Series "A" } & \multicolumn{7}{|c|}{ Series "B" } & \multicolumn{7}{|c|}{ Series "C" } \\
\hline & & \multicolumn{3}{|c|}{$\begin{aligned} \mathrm{F}_{\mathrm{G}} & =11.60 \mathrm{kN} \\
\mathrm{t}_{0} & =28 \text { days }\end{aligned}$} & \multicolumn{7}{|c|}{$\begin{array}{c}\mathrm{F}_{\mathrm{G}}=4.00 \mathrm{kN} \\
\mathrm{t}_{0}=365 \text { days }\end{array}$} & \multicolumn{7}{|c|}{$\begin{array}{c}\mathrm{F}_{\mathrm{G}+\mathrm{Q} / 2}=7.80 \mathrm{kN} \\
\mathrm{t}_{0}=365 \text { days }\end{array}$} \\
\hline & & $\begin{array}{c}a_{0} \\
{[\mathrm{~mm}]}\end{array}$ & $\begin{array}{c}\Delta^{*} \\
{[\%]}\end{array}$ & O/U & $\begin{array}{c}\mathrm{a}_{0} \\
{[\mathrm{~mm}]}\end{array}$ & $\begin{array}{c}\Delta^{*} \\
{[\%]}\end{array}$ & $\begin{array}{c}a_{t} \\
{[\mathrm{~mm}]}\end{array}$ & $\begin{array}{c}\Delta^{*} \\
{[\%]}\end{array}$ & $\begin{array}{c}a_{t}^{* *} \\
{[\mathrm{~mm}]}\end{array}$ & $\begin{array}{c}\Delta^{*} \\
{[\%]}\end{array}$ & O/U & $\begin{array}{c}\mathrm{a}_{0} \\
{[\mathrm{~mm}]}\end{array}$ & $\begin{array}{c}\Delta^{*} \\
{[\%]}\end{array}$ & $\left.\mid \begin{array}{c}a_{t} \\
{[\mathrm{~mm}]}\end{array}\right]$ & $\begin{array}{c}\Delta^{*} \\
{[\%]}\end{array}$ & $\begin{array}{c}\mathrm{a}_{\mathrm{t}}^{* *} \\
{[\mathrm{~mm}]}\end{array}$ & $\begin{array}{c}\Delta^{*} \\
{[\%]}\end{array}$ & O/U \\
\hline \multicolumn{2}{|c|}{ Experiment } & 3.60 & - & - & 0.490 & - & 1.88 & - & 1.39 & - & - & 1.925 & - & 4.88 & - & 2.95 & - & - \\
\hline \multirow{2}{*}{$\begin{array}{c}\text { Numerical } \\
\text { model }\end{array}$} & Beam & 4.45 & 23.61 & 0 & 0.460 & 6.12 & 1.46 & 22.34 & 1.00 & 28.06 & u & 2.34 & 21.56 & 4.84 & 0.82 & 2.50 & 15.40 & U \\
\hline & PL St. & 3.80 & 5.56 & 0 & 0.463 & 5.51 & 1.55 & 17.55 & 1.09 & 21.58 & U & 1.77 & 8.05 & 4.69 & 3.89 & 2.92 & 1.18 & U \\
\hline \multicolumn{2}{|c|}{ Analytical model } & 3.88 & 7.78 & 0 & 0.446 & 8.98 & 1.39 & 26.06 & 0.94 & 33.10 & u & 2.04 & 5.97 & 4.57 & 6.35 & 2.53 & 14.38 & U \\
\hline \multicolumn{2}{|c|}{ Code procedure $(\mathrm{m}=4)$} & 4.63 & 28.61 & 0 & 0.480 & 2.04 & 1.22 & 35.11 & 0.74 & 46.76 & u & 2.32 & 20.52 & 5.85 & 19.88 & 3.53 & 21.15 & 0 \\
\hline \multicolumn{2}{|c|}{ Code procedure $(m=3)$} & 4.03 & 11.94 & 0 & 0.480 & 2.04 & 1.22 & 35.11 & 0.74 & 46.76 & u & 1.93 & 0.26 & 4.87 & 0.21 & 2.94 & 0.51 & $u$ \\
\hline
\end{tabular}

also presented. Since reference beams have a reinforcement ratio of $0.54 \%$, they are considered in this simplified procedure as lightly reinforced elements, and therefore the power $m$ equal to 4 was introduced in Eq. (10). The deflections obtained with the power $m$ equal to 3 are also presented in Table 5 for comparison purposes. In Table 5, $a_{0}$ indicates the short-term instantaneous deflection, while $a_{t}$ is the final long-term deflection after one-year of exposure to different magnitude of sustained load. The time-dependent deflection caused by creep and shrinkage, denoted as $\Delta a_{t^{\prime}}$ is equal to the difference between the final long-term and instantaneous deflection. Table 5 shows that each result is within the allowable 30 $\%$ range of deviation from the experimentally obtained deflections, except for the results obtained with the simplified analytical procedure proposed in the current codes. The maximum deviation of these results occurs at the final long-term deflection of the uncracked beams "B", and amounts to $35.11 \%$. It can be noted that better prediction of short-term and long-term deflections is obtained with the power $m$ equal to 3 in Eq. (10). The results given in Table 5 show that each of the applied models overestimates the short-term deflections for the beam series " $A$ ", while underestimating in almost every case the long-term deflections for the beams " $\mathrm{B}$ " and " $\mathrm{C}$ ".

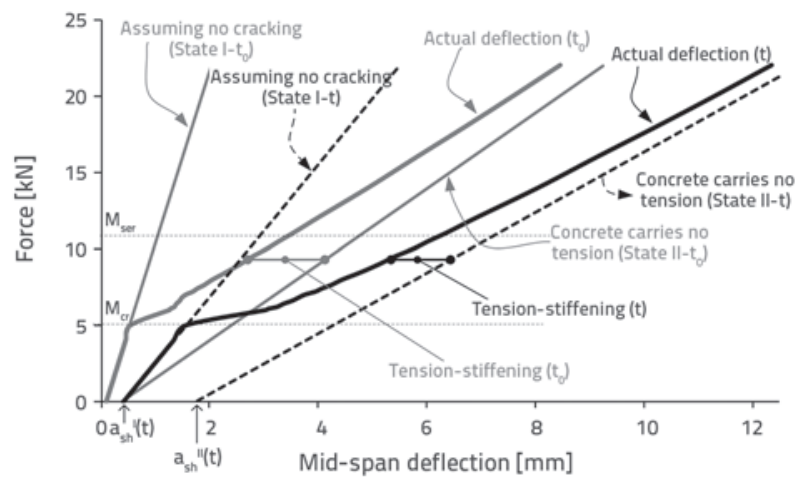

Figure 10. Effects of creep and shrinkage on the $F$ - a relation after one year of sustained load

The effects of creep and shrinkage on the long-term deflection of the analysed beams are illustrated in Figure 10. The grey curve shows the short-term deflection immediately after application of load. After the considered one year period, this curve shifts horizontally and is inclined to the right as a result of the simultaneous creep and shrinkage action (black curve). The force $(F)$ - deflection $(a)$ relation over time $t$ (black curve) shows that the element exhibits an initial deflection (denoted as $a_{s h}{ }^{\prime}(t)$ in Figure 10), even in the case of $M=0 \mathrm{kNm}$, which is due to the effect of shrinkage. Figure 9 also shows a reduction of beneficial tension-stiffening effects over time for loads higher than the cracking load. As the load increases, this reduction becomes more pronounced (Figure 10).

\subsection{Crack pattern}

A comparison of the numerically and experimentally obtained crack patterns in beams " $\mathrm{C}$ " is presented in this section. There is still no analytical procedure for obtaining crack locations and crack development over the element axis. Figure 10 shows the crack pattern at the initial load application time $t_{0}$ (28 days) and at time $t$ (365 days), from which the time-dependent nature of cracking can be observed. Some cracks develop through the element height over time, but new cracks also appear under sustained load, extending the cracking zone towards the element supports (Figure 11).

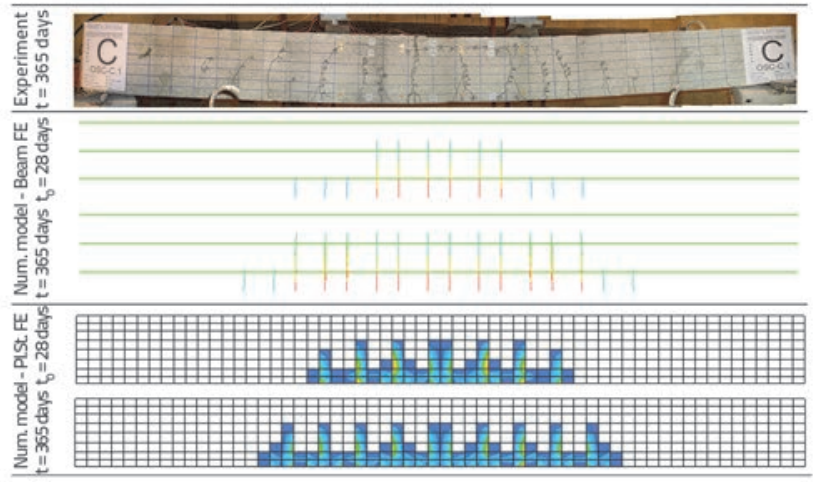

Figure 11. Crack pattern in beam series " $C$ " at the initial $\boldsymbol{t}_{0}$ and final time $t$ 
Unfortunately, Diana 9.4.3 is not able to present the crack widths explicitly. That is why crack widths were not compared in these investigations.

\section{Conclusion}

An analytical and numerical model for prediction of SLS of RC flexural members was applied to a reference beam. The results obtained with regard to time variation of stresses and strains, short and long-term deflections, and crack pattern, were compared with the existing experimental data.

Based on the results of comparative study presented in this paper, the following conclusions can be drawn:

- The analytical and numerical model efficiently takes into account the creep and shrinkage effects as well as the presence of cracking. Numerical models additionally provide a visual impression of the crack pattern and an insight into local behaviour of the element.

- The analytically and numerically predicted deflections show a reasonably good agreement with experimental data. A maximum deviation of $8.98 \%$ for short-term and 26.06 $\%$ for long-term deflections has been observed from the analytically obtained results. The results obtained with the numerical model with finite beam elements show $23.61 \%$ deviation for short-term deflections and $22.34 \%$ for longterm deflections. By contrast, the results of the numerical model with plane stress finite elements show a better agreement with experimental data, with $8.05 \%$ and $17.55 \%$ for short-term and long-term deflections, respectively. The deviations in both models with regard to experimental data are within the allowable $30 \%$ range [15].

- The bigger underestimation of the long-term deflections obtained with analytical model is especially due to the crude assumption of the loss of tension-stiffening with time, introduced only by the coefficient $\beta_{2}=0.50$ (Eq. (9)). The formation of new time-dependent cracks reduces beneficial effects of tension-stiffening and consequently affects the final value of long-term deflections. These effects should therefore be considered in more detail in order to make a reliable estimation of long-term deflection values.

- For the cases usually encountered in engineering practice, structural designers most often choose simplified code procedures based on Branson's model for prediction of inservice deflections. The results obtained in the scope of this study show that these procedures mostly underestimate actual deflections, pointing to the fact that more refined analytical models based on double integration of curvature can be recommended, even in simplest practical cases.

\section{REFERENCES}

[1] Gilbert, R.I.: Calculation of Long-Term Deflection, CIA Seminar Control of Long-Term Deflection - Brisbane, 23 April 2008.

[2] CEB Bulletin 235.: Serviceability Models, Bechaviour and Modelling in Serviceability Limit States Including Repeated and Sustained Loads-Progress Report, Comite Euro-International du Beton (CEB), April 1997.

[3] Jenkins, D.: Prediction of Cracking and Deflections; International Code Provisions and Recent Research.

[4] EN 1992-1-1: Design of Concrete Structures - Part 1-1: General Rules and Rules for Building, 2004.

[5] International Federation of Structural Concrete (FIB): fib Model Code for Concrete Structures 2010, Ernst \& Sohn, 2013.

[6] Arangjelovski, T.: Time-Dependent Behaviour of Reinforced HighStrength Concrete Elements under Action of Variable Loads, PhD dissertation, Faculty of Civil Engineering, Ss. Cyril and Methodius University, Skopje, September 2011.

[7] Arangjelovski, T., Markovski, G., Mark, P.: Influence of Repeated Variable Load on Long-Term Behavior of Concrete Elements, Journal of Civil Engineering and Architecture, USA, 8 (2014) 3 (Serial No. 76), pp. 302-314
[8] Beton i armiran beton prema BAB 87 Priručnik, Beograd 1995.

[9] Gilbert, R.I.: Time-Dependent Stiffness of Cracked Reinforced and Composite Concrete Slabs, Procedia Engineering, 57 (2013), pp. 19-34.

[10] Scott, R.H., Beebly, A.W.: Long-Term Tension-Stiffening Effects in Concrete, ACI Structural Journals, 102 (2005) 1, pp. 31-39.

[11] Zilch, K., Zehetmaier, G.: Bemessung im konstruktiven Betonbau nach DIN 1045-1 und EN 1992-1-1 (Eurocode 2)

[12] Ghali, A., Favre, R., Eldbadry, M.: Concrete Structures: Stresses and Deformation - Third Edition, Spon Press, London 2002.

[13] DIANA Release 9.4.3 User's Manual: Element Library, TNO DIANA

[14] DIANA Release 9.4.3 User's Manual: Material Library, TNO DIANA

[15] Chowdhury, S.H., Loo, Y.C.: A New Formula for Prediction of Crack Widths in Reinforced and Partially Prestressed Concrete Beams, Advances in Structural Engineering, 4 (2001) 2.

[16] Beebly, A.W., Scott, R.H.: Mechanisms of Long-Term Decay of Tension Stiffening, Magazine of Concrete Research, 58 (2006) 05, pp. 255-266. 